\title{
NOTA SOBRE O PLANO DE ALÉM DO BEM E DO MAL DE NIETZSCHE ${ }^{1}$ [NOTE ON THE PLAN OF NIETZSCHE'S BEYOND GOOD AND EVIL] ${ }^{2}$
}

\section{Leo Strauss ${ }^{3}$}

Além do bem e do $\mathrm{mal}^{4}$ sempre pareceu, para mim, ser o mais belo dos livros de Nietzsche. Esta impressão poderia ser contradita pelo seu próprio julgamento, pois ele próprio estava inclinado a acreditar que seu Zaratustra é o livro mais profundo que já foi escrito em língua alemã assim como o mais perfeito no que diz respeito à linguagem. Porém, "mais belo" não é o mesmo que "mais profundo" e até "mais perfeito no que diz respeito à linguagem". Para ilustrar isso, em parte por um exemplo que talvez não seja muito exagerado, parece haver um consenso geral sobre o fato de que a República de Platão, seu Fedro e seu Banquete são os

\footnotetext{
1 Tradução por Elvis de Oliveira Mendes. Mestre em Filosofia pela Universidade Federal de Pernambuco. Professor na UNIBRA, possui vários artigos sobre a filosofia política de Leo Strauss, publicados por diversas Revistas acadêmicas Brasileiras. Gostaria de agradecer ao Professor Dr. Richard Romeiro Oliveira (UFSJ) que me apresentou esse texto nos meandros de 2013 e me iniciou nos estudos sobre a filosofia política de Leo Strauss. Quero agradecer também ao Professor Dr. João Evangelista Tude de Melo Neto (UNICAP) pelo interesse e incentivo na publicação desta tradução e pela revisão do texto.

2 Tradução integral de: "Note on the Plan of Nietzsche's Beyond Good and Evil". In, STRAUSS, L. Studies in Platonic Political Philosophy. With an Introduction by Thomas Pangle. Chicago: The University of Chicago Press, 1983, pp. 174-191. Porém esse texto foi publicado pela primeira vez em: Note on the Plan of Nietzsche's Beyond Good and Evil. Interpretation 3, nos. 2-3 (Winter - 1973): 97-113.

${ }^{3}$ Nota do Tradutor: Leo Strauss ofereceu este seminário sobre o Além do bem e mal de Nietzsche na St John's College em Annapolis, Maryland. Curso que teve seu início em 6 de outubro de 1971 sendo concluído em 24 de maio de 1972. Leo Strauss é um filósofo político germano-americano, que por sua origem judaica, foi forçado ainda jovem a fugir de seu país com a ascensão do Nacional Socialismo alemão, durante maior parte de sua vida foi professor da Universidade de Chicago onde formou inúmeros estudantes e admiradores, se especializou em filosofia política clássica, mas também possui uma vastíssima produção sobre temas da filosofia medieval e, sobretudo acerca do pensamento moderno e contemporâneo, atualmente é considerado por muitos especialistas como um dos maiores filósofos políticos do século XX tendo um grande número de estudiosos e intérpretes de seu pensamento nos EUA, Canadá, Inglaterra, França e Alemanha, alcançando paulatinamente na últimas décadas países latinos europeus como Itália, Portugal e Espanha e nos últimos anos a América do Sul, inclusive o Brasil.

${ }^{4}$ Nota do tradutor: Tentei ser o mais fiel possível ao texto original, tarefa que me exigiu um esforço maior diante da complexidade da escrita straussiana, o leitor que já possui algum contato com a obra do professor de Chicago sabe a dificuldade que Strauss nos coloca, mesmo sendo um escritor claro e dono de um talento incrível para lidar com os mais variados temas da filosofia, Strauss é um defensor impetuoso do uso da escrita esotérica. Sendo assim, se trata de um intelectual preocupado com a estilística do texto, de fato quanto mais nos sentimos convidados para trilhar seus caminhos, mais temos a sensação de estarmos em um labirinto, diante da profundidade de suas abordagens. Nesse sentido, Strauss não entrega seus textos de forma gratuita ou apressada, o que torna às vezes a leitura de seus comentários, uma atividade árdua que exige do leitor paciência e atenção para o que ele mesmo chama de; ler por "entrelinhas". Portanto, há neste ensaio algumas passagens um pouco truncadas que podem ou irão deixar o leitor um pouco confuso. Ainda assim, insisto que fui fiel ao texto original para tentar não mudar o seu sentido, e imagino que, passagens truncadas fazem parte da estratégia do autor.
} 
seus mais belos escritos sem que sejam necessariamente seus escritos mais profundos. No entanto, Platão não faz distinção entre seus escritos em relação à profundidade, beleza ou perfeição no que se refere à linguagem; ele não se preocupou com Platão - com sua "ipsissimosidade" - e, sim, com os escritos de Platão, mas ele se afasta de si mesmo, enquanto Nietzsche aponta para ele mesmo, "o senhor Nietzsche". Agora, Nietzsche preferiu "pessoalmente". Não Além do Bem e do Mal, mas seu Aurora e seu Gaia Ciência do que todos os outros livros precisamente porque esses dois livros são seus livros "mais pessoais" (carta a Karl Knortz de 21 de junho de 1888). Como o próprio termo "pessoal", deriva da palavra grega para "rosto", indicar ser "pessoal" não tem nada a ver com ser "profundo" ou ser "perfeito em relação à linguagem".

O que é vagamente percebido e inadequadamente expresso através de nosso julgamento sobre Além do Bem e do Mal é claramente indicado por Nietzsche em seu relato sobre esse livro dado em Ecce Homo: Além do bem e do mal é o oposto do "inspirado" e do "ditirâmbico" Zaratustra, tanto quanto o Zaratustra é mais perspicaz, enquanto que em Além do bem e do mal o olho é obrigado a compreender claramente o mais próximo, o oportuno (o presente), o "entrenós" Esta mudança de preocupação requer, em todos os aspectos, "sobretudo também na forma", o mesmo desvio arbitrário dos instintos de que um Zaratustra tornou-se possível: a graciosa sutileza quanto à forma, no que diz respeito à intenção, no que se refere à arte do silêncio estão em primeiro plano em Além do bem e do mal, o que equivale a dizer que essas qualidades não estão em primeiro plano no Zaratustra, sem falar nos outros livros de Nietzsche.

Em outras palavras, em Além do bem e do mal, no único livro publicado por Nietzsche, no prefácio contemporâneo ao qual ele se apresenta como antagonista de Platão, ele "platoniza" quanto à "forma" mais do que em qualquer outro lugar.

De acordo com o prefácio de Além do bem e do mal, o erro fundamental de Platão foi a sua invenção da razão pura e do bem em si. A partir desta premissa, pode-se facilmente chegar à conclusão de Diotima de que nenhum ser humano é sábio, mas apenas um deus o é; os seres humanos só podem lutar pela sabedoria ou filosofar; os deuses não filosofam (Banquete 203e 204a) ${ }^{5}$. No penúltimo aforismo de Além do bem e do mal em que Nietzsche delineia "o gênio do coração" - um super-Sócrates que é de fato o deus Dionísio de Nietzsche

\footnotetext{
${ }^{5}$ Nota do tradutor: No que diz respeito à forma de citação mantive a mesma usada por Strauss, mais uma vez a fim de ser fiel ao texto original e as intenções do autor.
} 
divulga após a preparação adequada a novidade, suspeita, talvez, especialmente entre os filósofos, que os deuses também filosofam. No entanto, Diotima não é Sócrates, nem Platão, e Platão poderia ter pensado que os deuses filosofam (cf. O Sofista 216b5-6, Teeteto 151d 1-2). E quando no último aforismo de Além de bem e do mal Nietzsche sublinha a diferença fundamental entre "pensamentos escritos e pintados" e pensamentos na sua forma original, não podemos deixar de lembrar o que Platão diz ou diz com respeito à "fraqueza do logos" e no que se refere ao caráter insensível e mais errado da verdade (a seguir, VII 341c-d, 342e343a): a pureza da razão como Platão a concebe, não estabelece necessariamente a força do logos.

Além do bem e do mal tem o subtítulo "Prelúdio para uma filosofia do futuro". O livro destina-se a preparar, não a filosofia do futuro de fato, a verdadeira filosofia, mas um novo tipo de filosofia, libertando a mente do "preconceito dos filósofos", ou seja, dos filósofos do passado (e do presente). Ao mesmo tempo ou por este mesmo fato, o livro deve ser um exemplar da filosofia do futuro. O primeiro capítulo ("Dos preconceitos dos filósofos") é seguido por um capítulo intitulado "O espírito livre" ${ }^{6}$. Os espíritos livres no sentido de Nietzsche são livres do preconceito da filosofia do passado, mas ainda não são filósofos do futuro; eles são os arautos e precursores da filosofia do futuro (aforismo 44). É difícil dizer como a distinção entre os espíritos livres e os filósofos do futuro deve ser compreendida: será que os espíritos livres podem ser mais livres do que os filósofos do futuro? Eles possuem uma abertura que só é possível durante o período de transição entre a filosofia do passado e a filosofia do futuro? Seja como for, a filosofia é certamente o tema principal de Além do bem e do mal, o tema óbvio dos dois primeiros capítulos.

O livro é composto por nove capítulos. $\mathrm{O}$ terceiro capítulo é dedicado à religião. $\mathrm{O}$ título do quarto capítulo ("Provérbios e Interlúdios") não indica um assunto; esse capítulo se distingue de todos os outros capítulos pelo fato de que consiste exclusivamente em aforismos curtos. Os últimos cinco capítulos são dedicados à moral e à política. $\mathrm{O}$ livro como um todo consiste então em duas partes principais que são separadas umas das outras por cerca de 123 "provérbios e interlúdios"; a primeira das duas partes é dedicada principalmente à filosofia e à religião e a segunda, principalmente à moral e à política. Filosofia e religião, ao que parece, pertencem à um conjunto - pertencem mais estreitamente que a filosofia e a cidade (Cf. A

\footnotetext{
${ }^{6}$ Nota do tradutor: Do alemão "Der Freie Geist", Strauss em seu texto usa o termo em inglês "The Free Mind" p. 175, dei preferência por traduzir por "O Espírito Livre", já que esta é a tradução mais usada no Brasil diretamente do alemão, mas poderia ser também "a mente livre".
} 
distinção de Hegel entre o espírito absoluto e o espírito objetivo). A alternativa fundamental é a da regra da filosofia sobre a religião ou a regra da religião sobre a filosofia; não é, como foi para Platão ou Aristóteles, a do filosófico e a vida política; para Nietzsche, assim distinto dos clássicos, a política pertence desde o início a um plano mais baixo do que a filosofia ou a religião. No prefácio ele insinua que seu precursor por excelência não é um estadista nem mesmo um filósofo, mas o homo religiosus Pascal (cf. aforismo 45).

Nietzsche diz muito pouco sobre a religião nos dois primeiros capítulos. Pode-se dizer que fala na religião somente em um único aforismo que é o mais curto (37). Esse aforismo é um tipo de corolário para o precedente imediatamente anterior, no qual ele declara da maneira mais direta e inequívoca que é compatível com sua intenção, o caráter particular de sua proposição fundamental segundo a qual a vida é vontade de poder ou vista de dentro o mundo é vontade de poder e nada mais. A vontade de poder toma o lugar que o eros - o esforço para "o bem em si" - ocupa o pensamento de Platão. Mas o eros não é "o espírito puro"" (der reine geist). Seja qual for a relação entre o eros e o espírito puro de acordo com Platão, no pensamento de Nietzsche a vontade de poder ocupa o lugar do eros e do espírito puro. Assim, filosofar torna-se um modo ou modificação da vontade de poder: é a vontade mais espiritual (der geistigste) de poder; consiste em prescrever a natureza o que ou como deve ser (aforismo 9); não é o amor da verdade que é independente de vontade ou decisão. Considerando que, de acordo com Platão, a razão pura absorve a verdade, de acordo com Nietzsche, a razão impura, ou certo tipo de razão impura, é a única fonte de verdade. Nietzsche começa, portanto, Além do bem e do mal com o questionamento do amor da verdade e à verdade. Se pudermos fazer um uso um tanto livre de uma expressão que ocorre na Segunda Meditação de Nietzsche, a verdade não é atraente, adorável, vivificante, mas mortal, como é demonstrado pelas verdadeiras doutrinas da soberania da transformação, da fluidez de todos os conceitos, tipos e espécies e da falta de qualquer diferença cardinal entre homem e fera (Werke, ed Schlechta, I 272); é mostrado mais simplesmente pela verdadeira doutrina de que Deus está morto. O mundo em si, a "coisa em si”, "natureza" (aforismo 9) é totalmente caótica e sem sentido. Daí todo significado, toda ordem se origina no homem, nos atos criativos do homem, em sua vontade de poder. As declarações ou sugestões de Nietzsche são deliberadamente enigmáticas (aforismo 40). Ao sugerir ou dizer que a verdade é mortal, ele faz o melhor para quebrar o poder dessa verdade mortal; ele sugere que o mais importante, a verdade mais abrangente - a

\footnotetext{
${ }^{7}$ Nota do tradutor: Mais uma vez, Strauss usa o termo "Mind" no inglês para traduzir "Geist" do alemão. 
verdade em relação a todas as verdades - é a vida-dada. Em outras palavras, sugerindo que a verdade é uma criação humana, ele sugere que esta verdade, de qualquer forma, não é uma criação humana. Ele está tentando dizer que a razão pura de Nietzsche compreende o fato de que a razão impura cria verdades perecíveis. Resistindo a essa tentação, declaramos a sugestão de que Nietzsche seguindo-o desta maneira: os filósofos tentaram se apossar do "texto" como distinto das "interpretações"; eles tentaram "descobrir" e não "inventar". O que Nietzsche afirma ter percebido é que o texto é puro, a forma infalível é inacessível (como a coisa em si de Kant); todo pensamento de qualquer - filósofo ou homem do povo - é, em última análise interpretação. Mas, por essa razão, o texto, o mundo em si, o mundo verdadeiro não pode nos preocupar; o mundo de qualquer preocupação para nós é necessariamente uma ficção, pois é necessariamente antropocêntrico; o homem é necessariamente de alguma maneira a medida de todas as coisas (aforismo 3 fim, 12 fim, 17, 22, 24, 34, 38; Cf. Platão, Leis 716c 4-6). Conforme indicado de forma suficiente pelo título do livro, o antropocentrismo para o qual Nietzsche opta é transmoral (ver aforismo 34 e 35 com 32). À primeira vista, não parece haver uma conexão entre o grave aforismo 34 e o aforismo alegre. Isso parece concordar com a impressão geral segundo a qual um livro de aforismos não têm ou não precisa ter uma ordem lúcida e necessária pode consistir em peças desconectadas. A conexão entre o aforismo 34 e o 35 é um exemplo particularmente impressionante da lúcida, talvez escondida, ordem que governa a sequência dos aforismos: o caráter desnecessário do argumento de Nietzsche é mais pretendido do que real. Se o acima mencionado estiver correto, a doutrina da vontade de poder não pode reivindicar revelar o que é, o fato, o mais fundamental fato, mas é "apenas" uma interpretação, presumivelmente a melhor interpretação, entre muitas. Nietzsche considera esta aparente objeção como confirmação de sua proposição (aforismo 22 fim).

Podemos agora recorrer aos dois aforismos em Além do bem e do mal que podem ser considerados dedicados à religião (36-37). O aforismo 36 apresenta o raciocínio em apoio à doutrina da vontade de poder. Nietzsche falou da vontade de poder antes, mas apenas no caminho da afirmação direta, para não dizer dogmaticamente. Agora, ele estabelece com o que é ao mesmo tempo a probidade intelectual mais intransigente e a brincadeira mais encantada de seus motivos, ou seja, o caráter problemático, provisório, tentador e hipotético de sua proposição. Parece que ele não reconhece mais a vontade de poder tal como realidade fundamental do que então ele diz aqui. Quase imediatamente antes, no aforismo central do segundo capítulo (Aforismo 34), ele chamou nossa atenção para a distinção fundamental entre 
o mundo que nos interessa e o mundo em si mesmo, ou entre o mundo da aparência ou da ficção (As interpretações) e o mundo verdadeiro (o texto). O que ele parece apontar é a abolição dessa distinção fundamental, o mundo como vontade de poder é o mundo de qualquer preocupação para nós e para o mundo em si. Precisamente, se todas as visões de mundo são interpretações, isto é, atos da vontade de poder, a doutrina da vontade de poder é ao mesmo tempo uma interpretação e o fato mais fundamental, pois, em contradição com todas as outras interpretações, é a condição necessária e suficiente da possibilidade de qualquer uma das "categorias".

Depois de ter tentado alguns de seus leitores (Ver o aforismo 30) com a doutrina da vontade de poder, Nietzsche os faz levantar a questão de saber se essa doutrina não afirma, para falar popularmente, que Deus é refutado, mas o diabo não é. Ele responde: "pelo contrário! Sobre o conflito, meus amigos! E, ao diabo, o que te obriga a falar popularmente?" A doutrina da vontade de poder - toda a doutrina de Além do Bem e do Mal - é de uma maneira que é uma reivindicação de Deus. (Cf. aforismos 150 e 295, cf. também Genealogia da Moral, Prefácio Nr. 7).

O terceiro capítulo é intitulado “Das religiose Wesen” (A natureza religiosa); não é intitulado "Das Wesen der Religion" (A essência da religião) ${ }^{8}$, uma das razões para o fato de que a essência da religião, o que é comum a todas as religiões, não é ou não deve ser de qualquer preocupação para nós. O capítulo considera a religião com vista para a alma humana e seus limites, a toda a história da alma até agora e ainda há possibilidades inesgotáveis: Nietzsche não lida com possibilidades desconhecidas, embora ou porque ele lida com a religião até então e a religião do futuro. Os aforismos 46-52 são dedicados à religião até então e 53-57 a religião do futuro. O resto do capítulo (aforismos 58-62) transmite a avaliação de Nietzsche da religião como um todo. Na seção sobre religião até então ele fala primeiro do cristianismo (46-48), então dos gregos (49), em seguida novamente do cristianismo (50-51) e, finalmente, do Antigo Testamento (52). "A religiosidade dos antigos gregos" e, acima de tudo, certas partes do antigo testamento judaico que lhe fornecem os padrões pelos quais ele julga o cristianismo; em lugar nenhum do capítulo ele fala do cristianismo com respeito, a admiração, a veneração com que ele fala dos dois fenômenos pré-cristãos. Os aforismos sobre os antigos gregos e do Antigo Testamento é, obviamente, destinado a interromper os

\footnotetext{
${ }^{8}$ Nota do tradutor: De fato, ora Strauss traduz o termo do alemão Wesen por Nature (natureza), ora por Essence no inglês (essência).
} 
aforismos dedicados à Cristandade; os dois aforismos de interrupção são colocados a alguma distância de um ao outro para imitar a distância, ou melhor, a oposição entre o que se pode chamar de Atenas e Jerusalém. O aforismo sobre o Antigo Testamento é imediatamente precedido por um aforismo dedicado ao santo: não há santos, nem homens santos no Antigo Testamento; a peculiaridade da teologia do Antigo Testamento em oposição à teologia grega é a concepção, a criação do Deus santo (cf. Aurora, aforismo 68). Para Nietzsche, "o grande estilo" (de certas partes) do Antigo Testamento mostra a grandeza, não de Deus, mas do que era o homem: o Deus santo, não menos que o homem santo, são criaturas da vontade humana de poder.

A reivindicação de Deus por Nietzsche é então ateísta, pelo menos por enquanto: o aforismo que se segue ao Antigo Testamento começa com a pergunta "Por que o ateísmo atual?" Houve um tempo em que o teísmo era possível ou necessário. Mas, no entanto, "Deus morreu" (Assim falou Zaratustra, Prólogo de Zaratustra Número 3). Isso não significa meramente que os homens pararam de acreditar em Deus, porque a incredulidade dos homens não destrói a vida de Deus ou do ser. Isso significa, no entanto, que, mesmo que Deus vivesse, ele nunca foi o que os crentes nele pensavam que ele era, isto é, imortal. O teísmo foi compreendido, portanto, sempre de forma errada. No entanto, por um tempo era verdade, ou seja, poderoso, vida-dada. Ao falar de como ou por que este perdeu o poder, Nietzsche diz aqui menos dos motivos que o influenciaram do que os motivos avançados por alguns de seus contemporâneos, presumivelmente seus contemporâneos mais competentes. Nem alguns de seus melhores leitores irão justificadamente pensar que esses motivos abordam o frívolo. Em particular, não está bem claro se as razões são dirigidas contra a teologia natural (racional) ou revelada. Mesmo assim, o argumento anti-teísta mais poderoso que Nietzsche esboça é dirigido contra a possibilidade de uma revelação clara e inequívoca, ou seja, de Deus "falando" para o homem (cf. Aurora 91 e 95). Apesar da decadência do teísmo europeu, Nietzsche tem a impressão de que o instinto religioso - "religiosidade" como distinto da "religião" - cresce poderosamente no momento ou o ateísmo é apenas uma fase de transição. O ateísmo pertence ao espírito livre como Nietzsche o concebe, enquanto um certo tipo de não-ateísmo pertence ao filósofo do futuro que mais adora o deus Dionysos ou será novamente, como pode dizer um epicurista, um dionysokolax (Ver aforismo 7)? Essa ambiguidade é essencial para o pensamento de Nietzsche; sem ela sua doutrina perderia seu caráter de experiência ou tentação. 
Nietzsche ilustra provisoriamente a sua sugestão de uma religiosidade ateísta ou, se desejar, não-teísta pelo alegado fato de que toda a filosofia moderna era anticristã, mas não antirreligiosa, que poderia parecer apontar para algo lembrando a filosofia Vedanta. Mas ele não antecipa, certamente não deseja, que a religião do futuro seja algo como a filosofia Vedanta. Ele antecipa uma possibilidade mais ocidental, mais severa, mais terrível e mais revigorante: o sacrifício da crueldade, ou seja, da vontade de se transformar contra si mesmo, de Deus que prepara a adoração da pedra, a estupidez, o peso (gravidade), o destino, o nada. Ele antecipa, em outras palavras, que os melhores entre os ateus contemporâneos chegarão a saber o que estão fazendo - "a pedra" pode nos lembrar do desapontamento do sol de Anaxágoras, que eles perceberão que há algo infinitamente mais terrível, deprimente e degradante do que o foeda religio (um serviço de base) ou l'infdme: a possibilidade, e o fato de que a vida humana é totalmente sem sentido e sem suporte, que dura apenas um minuto que é precedido e seguido por um tempo infinito durante o qual o humano e a raça não foi e não será (Cf. o início de "Sobre a verdade e a mentira em um sentido extra-moral") estes ateus religiosos, essa nova raça de ateus não podem ser enganosamente apaziguados como pessoas, como Engels pela perspectiva de um futuro muito glorioso, do reino da liberdade, que acabará com a aniquilação da raça humana e com todos os significados, mas que durará muito tempo - por milênio ou mais -, pois, felizmente, nos encontramos ainda "no ramo ascendente da história humana" (F. Engels, Ludwig Feuerbach und der Ausgang der deutschen klassischen Philosophie): a reabilitação da liberdade, destinada a perecer, contém necessariamente em si as sementes de sua aniquilação e, portanto, enquanto dure, abundam em "contradições" tanto quanto qualquer idade anterior.

Nietzsche não quer sacrificar a Deus em prol do Nada, pois ao reconhecer a verdade mortal que Deus morreu, ele pretende transformá-la em uma vida inspiradora, ou melhor, para descobrir no âmago dessa verdade mortal o seu oposto. Sacrificar Deus por causa do nada seria uma forma extrema de negação do mundo ou de pessimismo. Mas Nietzsche, motivado por "Algum desejo enigmático", tentou por muito tempo penetrar no pessimismo para suas profundezas e, em particular, liberá-lo da ilusão da moralidade que, de certa maneira contradiz sua tendência de negar o mundo. Ele assim compreendeu um modo de pensar que negava o mundo de qualquer pessimista anterior. Ainda assim, um homem que tomou este caminho talvez não tenha intenção de fazê-lo, isso abriu os olhos para o ideal oposto - para o ideal que pertence à religião do futuro. Supérfluo será dizer que o que em alguns outros homens era "talvez", o caso fosse um fato no pensamento e na vida de Nietzsche. A adoração 
do nada prova ser a transição indispensável de todos os tipos de negação do mundo ao mais ilimitado sim: o eterno Sim - dizendo a tudo isso foi e é, ao dizer sim a tudo o que foi e é, Nietzsche pode se revelar como radicalmente antirrevolucionário ou conservador além dos desejos mais selvagens de todos os outros conservadores, que todos dizem não a algumas das coisas que eram ou são. Lembrando as restrições de Nietzsche contra "Ideais" e "idealistas", somos lembrados das palavras de Goethe para Eckermann (24 de novembro de 1824) de acordo com o qual "toda ideia (jedes Ide-elle) é útil para fins revolucionários". Seja como for, "e isso", Nietzsche conclui sua sugestão sobre a eterna repetição de o que era e é, "não seria circulus vitiosus deus?" À medida que esta questão ambígua e conclusiva mostra novamente, que seu ateísmo não é inequívoco, pois ele tinha dúvidas sobre se pode haver um mundo, qualquer mundo cujo centro não é Deus (Aforismo 150). A conclusão do presente aforismo nos lembra, através da sua forma, o aforismo teológico que ocorre nos dois primeiros capítulos (37), onde Nietzsche traz o fato de que, de certa forma, a doutrina da vontade de poder é uma reivindicação de Deus, se Uma reivindicação decididamente não teísta de Deus.

Mas agora somos confrontados com o fato de que a reivindicação de Deus é apenas a inversão do sacrifício de Deus à estupidez, ao nada, ou pelo menos, pressupõe sacrifício. $\mathrm{O}$ que é isso de repente, se depois de uma longa preparação, diviniza o nada? É a vontade da eternidade que dá ao mundo, ou restaura, vale a pena que os modos de pensar de negação do mundo o negassem? É a vontade da eternidade que faz o ateísmo religioso? A amada eternidade é divina, simplesmente porque é amada? Se dissermos que deve ser em si adorável, para merecer ser amado, não nos tornaríamos culpados de uma recaída no platonismo, no ensino do "bem em si"? Mas podemos evitar essa recaída no total? Para o eterno a que Nietzsche diz que sim, não é a pedra, a estupidez, o nada que, mesmo que eterno ou sempiterno, não possa despertar um sim entusiástico e inspirador da vida. Sim. A transformação da maneira de pensar negando o mundo ao ideal oposto está relacionada com a realização ou adivinhação de que a pedra, a estupidez ou o nada a que Deus está sendo sacrificado, é em seu “caráter inteligível” a vontade de poder (cf. aforismo 36).

Existe um ingrediente importante. Para não dizer o nervo da "teologia" de Nietzsche, da qual não falei e não falo, pois não tenho acesso a ela. Tem sido dignamente tratado por Karl Reinhardt em seu ensaio "Klage der Ariadne de Nietzsche” (Vermiichtnis der Antike, Gottingen 1960, 310-333; veja também uma observação de Reinhardt no final de seu elogio de Walter F. Otto. Ib. 379). 
É possível, mas não é provável que os "provérbios e interlúdios" do qual o quarto capítulo consiste, não possuam ordem, que não tenha rima ou razão para sua seleção e sequência. Devo deixar questões em algumas observações que talvez sejam úteis para alguns de nós.

O aforismo de abertura chama nossa atenção para a supremacia de si mesmo, de ser para si mesmo, de "preservar-se" (ver aforismo 41). Adequadamente o conhecimento não pode ser, ou não pode ser bom, por seu próprio bem; é justificável apenas como autoconhecimento: ser a si mesmo significa ser honesto consigo mesmo, seguir o caminho para o próprio ideal. Isso parece ter implicações ateístas. Ocorrem no capítulo nove referências a Deus; apenas um deles aponta para a própria teologia de Nietzsche (150). Ocorre apenas uma única referência à natureza (126). Em vez disso, somos confrontados com nove aforismos dedicados à mulher e ao homem. Certamente, o conhecedor a quem Nietzsche tem em mente não tem, como Kant, o céu estrelado acima de si mesmo. Como consequência, ele tem uma moral elevada, uma moral além do bem e do mal e, em particular, além do puritanismo e do ascetismo. Precisamente porque ele se preocupa com a liberdade de sua mente, ele deve aprisionar seu coração $(87,107)$. A liberdade da mente não é possível sem um traço de estupidez (9). O autoconhecimento não é apenas muito difícil, mas impossível de alcançar; o homem não poderia viver com autoconhecimento perfeito $(80-81$. 231, 249).

O quinto capítulo - o capítulo central - é o único cujo título ("Rumo à história natural da moralidade") se refere à natureza. A natureza pode ser o tema deste capítulo ou mesmo de toda a segunda parte do livro? A natureza - para não falar de "naturalistas", "física" e "fisiologia", havia sido mencionada mais de uma vez nos quatro primeiros capítulos. Vamos lançar um olhar sobre a mais importante ou impressionante dessas menções. Ao discutir e rejeitar o imperativo estoico "viver de acordo com a natureza", Nietzsche faz uma distinção entre a natureza e a vida $(9 ; 49)$, assim como em outra ocasião ele faz uma distinção entre a natureza e "nós" (seres humanos) ( 22). O oposto da vida é a morte que é ou não pode ser menos natural do que a vida. O oposto do natural é o não natural: o artificial, o domesticado, o mal-intencionado (62), o antinatural (21. 51, 55); ou seja, o não natural pode muito bem estar vivo.

No aforismo introdutório (186) Nietzsche fala do desideratum de uma história natural da moralidade de uma maneira que nos lembra do que ele havia dito no aforismo introdutório do capítulo sobre a religião (45). Mas no caso anterior, ele nos levou a suspeitar que a 
verdadeira ciência da religião, ou seja, a psicologia empírica da religião, é para todos os propósitos práticos impossível, pois o psicólogo teria de estar familiarizado com a experiência religiosa dos mais famosos homines religiosi e, ao mesmo tempo, poder olhar para baixo, sobre essas experiências. No entanto, ao afirmar o caso de um estudo empírico, uma descrição, das diversas moralidades, Nietzsche afirma, ao mesmo tempo, o caso contra a possibilidade de uma ética filosófica, uma ciência da moral que ensina a única verdadeira moralidade. Parece que ele faz maiores exigências ao aluno de religião do que ao aluno da moralidade. Essa é talvez a razão pela qual ele não desse direito ao terceiro capítulo "A história natural da religião": Hume havia escrito um ensaio intitulado "A História Natural da Religião".

A ciência da moral dos filósofos afirmou ter descoberto a fundação da moral, quer na natureza, quer na razão. Além de todos os outros defeitos daquela pretendida ciência, ela se baseia na suposição gratuita de que a moralidade deve ou pode ser natural (de acordo com a natureza) ou racional. Ainda assim, toda moralidade é baseada em alguma tirania contra a natureza e contra a razão. Nietzsche dirige suas críticas especialmente contra os anarquistas que se opõem a toda sujeição a leis arbitrárias: tudo de valor, toda liberdade surge de uma compulsão de longa duração que foi exercida por leis arbitrárias e irracionais; foi essa compulsão que educou a mente para a liberdade. Contra a permissividade ruinosa do anarquismo, Nietzsche afirma que precisamente a obediência lúcida e longa a um nome pouco natural e irracional é "o imperativo moral da natureza". Physis apela para nomoi, preservando a distinção, e a oposição de physis e nomos. Ao longo deste aforismo (188) Nietzsche fala da natureza apenas entre aspas, exceto em um caso, na menção final da natureza; a natureza, e não apenas à natureza, como os anarquistas entendem, tornou-se um problema para Nietzsche e, no entanto, ele não pode fazer nada sem a natureza.

Assim a moralidade racionalista consiste principalmente na identificação do bom com o útil e agradável e, portanto, no cálculo das consequências; é utilitário. Seu exemplo clássico é o Sócrates plebeu. Como o patrício Platão - "o mais belo crescimento da antiguidade" (Prefácio), cuja força e o poder eram o maior que até agora um filósofo tinha à sua disposição - poderia assumir o ensino socrático, é um enigma; o Sócrates platônico é uma monstruosidade. Nietzsche pretende então superar Platão não só por substituir sua verdade por Platão, mas também o superando em força ou poder. Entre outras coisas, "Platão é chato" (Crepúsculo dos deuses, "o que eu devo aos antigos" n. 2), enquanto Nietzsche certamente 
nunca é chato. Ambos, Sócrates e Platão são guiados por, ou seguem, não só a razão, mas instinto como bem; uma vez que o instinto é mais fundamental do que a razão. Ao tomar explicitamente o lado do instinto contra a razão, Nietzsche concorda tacitamente com Rousseau (cf. Natural Right and History p. 262). O instinto é, pelo menos, semelhante à natureza - para o que se pode expulsar com um tridente, mas, no entanto, sempre retorna (ver o aforismo 264 veja o título em itálico do aforismo 83, o primeiro dos quatro títulos em itálico no capítulo quatro). Temos o direito de supor que o instinto fundamental é a vontade de poder e não, digamos, o desejo para a autopreservação (ver aforismo 13). O que arriscamos a chamar de religiosidade de Nietzsche também é um instinto (aforismo 53): "O religioso, isto é, a "forma-Deus" do instinto (Vontade de Poder n. 1038)". Como consequência da irracionalidade do julgamento moral, da presença decisiva do irracional no julgamento moral, não pode haver, portanto, normas morais universalmente válidas: diferentes tipos de moralidade pertencem a diferentes tipos de seres humanos.

Quando Nietzsche fala novamente da natureza, fornecendo o termo novamente com aspas (aforismo 197), ele exige que alguém deixe de considerar como mórbido (como defeituosamente natural) os seres predatórios que são perigosos, intemperantes, apaixonados, "tropicais": foi precisamente a natureza defeituosa de quase todos os moralistas - não a razão e não a natureza simplesmente -, ou seja, sua timidez que os induziu a conceber os perigosos brutos e os homens como mórbidos. Estes, os moralistas não originaram a moral derivada da timidez; Essa moralidade é a moralidade do rebanho humano, isto é, da grande maioria dos homens. O máximo que poder-se-ia dizer é que os filósofos morais (E teólogos) tentaram proteger o indivíduo contra os perigos com os quais ele está ameaçado, não por outros homens, mas por suas próprias paixões.

Nietzsche fala do instinto de obediência do rebanho que agora é quase universalmente inato e transmitido por herança. Supérfluo será dizer que originalmente, nos tempos préhistóricos, esse instinto foi adquirido (ver Genealogia da Moral II). Embora tenha sido muito poderoso ao longo da história, tornar-se simplesmente predominante na Europa contemporânea, onde destrói ao menos a boa consciência daqueles que comandam e são independentes e onde afirma com sucesso ser a única verdadeira moralidade. Mais precisamente, em sua forma mais jovem e saudável implicou que o único padrão de bondade é de utilidade para o rebanho, ou seja, para o bem comum; independência, superioridade, a desigualdade era estimada na medida em que eles eram pensados para ser subservientes ao 
bem comum e indispensável para ele, e não para o seu próprio bem. O bem comum foi entendido como o bem de uma sociedade particular ou tribo; isso exigiu, portanto, hostilidade aos inimigos externos e internos da tribo, em particular, aos criminosos. Quando a moralidade do rebanho desenha suas últimas consequências como acontece na Europa contemporânea, isso leva a parcela dos muitos criminosos que tem medo de infligir à punição; isto é satisfeito ao tornar os criminosos inofensivos; abolindo o único domínio restante do medo, a moralidade da timidez chegaria a sua conclusão e assim tornar-se-ia supérflua (ver aforismo 73). A Timidez e a abolição do medo são justificadas pela identificação de bens com indiscriminada compaixão.

Antes da vitória do movimento democrático ao qual, como Nietzsche entende, também pertencem os anarquistas e os socialistas, os outros mais do que a moral do rebanho foram pelo menos conhecidas. Ele menciona com alto elogio Napoleão e, acima de tudo, Alcibíades e César. Ele não poderia ter mostrado sua liberdade da moral do rebanho como mais importante do que mencionando de uma só vez, César e Alcibíades. César poderia dizer que desempenhou uma ótima função histórica para Roma e se dedicou a essa função - ter sido, por assim dizer, funcionário da história romana, mas para Alcibíades Atenas não era mais do que o pedestal, permutável se precisa estar com Esparta ou Pérsia, para sua própria glória ou grandeza. Nietzsche se opõe a homens de tal natureza aos homens de natureza oposta (Aforismo 199-24). No resto do capítulo, ele não fala mais da natureza. Em vez disso, ele expressa a visão de que o homem deve ser contado literalmente entre os brutos (aforismo 202). Ele apela à moral vitoriosa da Europa contemporânea à moral superior dos líderes (Füher). Os líderes que podem contrariar a degradação do homem que levou à autonomia do rebanho, pode, no entanto, não ser homens meramente nascidos para governar como Napoleão, Alcibíades e César. Eles devem ser filósofos, novos filósofos, um novo tipo de filósofos e comandantes, os filósofos do futuro. Mere Caesars, por mais que excelente não basta, pois os novos filósofos devem ensinar ao homem, o futuro do homem como sua vontade, como dependente de uma vontade humana, para pôr fim à regra horrível do absurdo e a chance que até então era considerada como "História": a verdadeira história - como distinta da mera pré-história. Para usar uma distinção marxista - requer a subjugo do acaso, da natureza por homens da mais alta espiritualidade, de razão maior. O subjugo da natureza depende então de forma decisiva de homens que possuem uma determinada natureza. Filosofia, ouvimos, é a mais espiritual vontade de poder (Genealogia da Moral II. n. 2) os filósofos do futuro devem possuir essa vontade num grau que nem sequer sonhou com a 
filosofia do passado; eles devem possuir essa vontade em sua forma absoluta. Os novos filósofos são ou agem, nós somos tentados a dizer, ao mais alto grau de acordo com a natureza. Eles são ou agem também no mais alto grau de acordo com o motivo, pois eles colocam um fim da regra de desrazão e o alto - a alta espiritualidade independente, a vontade de ficar sozinho, o grande motivo (aforismo 201) - é evidentemente preferível ao baixo. A volta da autonomia do rebanho ao domínio dos filósofos do futuro é semelhante à transformação da adoração do nada para o sim ilimitado para tudo o que era e é; essa transformação também seria evidentemente razoável.

Mas o que se torna então de irracional do julgamento moral, isto é, de todo julgamento moral (aforismo 191)? Ou deixa de ser racional meramente porque é preciso ser forte, saudável e bem-nascido para concordar com ele ou até mesmo para entender isto? No entanto, pode-se dizer que o louvor de Nietzsche à crueldade, como distinto do louvor de Platão à gentileza, é racional? Ou é esse elogio à crueldade, apenas o indispensável e, portanto, o corretivo razoável para a glorificação irracional da compaixão (cf. Genealogia da Moral, prefácio, n. 5 final)? Além disso, não é a crítica de Nietzsche a Platão e a Sócrates um grave exagero, para não dizer uma caricatura? Basta lembrar a diferença entre o Protágoras e o Górgias para ver que Sócrates não era um utilitário no sentido de Nietzsche (ver aforismo 190). Como Nietzsche diz no mesmo Capítulo (202), Sócrates não pensou que sabia o que é o bem e o mal. Em outras palavras, "virtude é conhecimento" é um enigma em vez de uma solução. O enigmático ditado de Sócrates baseia-se na consciência do fato de que as vezes "uma cabeça científica é colocada no corpo de um macaco, um subtil excepcional de compreensão sobre uma alma vulgar" (Aforismo 26), implica consciência de complexidade da relação entre Wissen (conhecimento) e Gewissen (Crença), para usar uma distinção favorita de Nietzsche que, dessa forma, é de fato estranha a Sócrates. Para considerações como essas é obrigada a retorcer isso, já que para Nietzsche não pode haver uma moral natural ou racional porque ele nega que haja uma natureza do homem: a negação de qualquer diferença cardinal entre o homem e a fera é uma verdade, uma verdade mortal; portanto, não pode haver fins naturais do homem como homem: todos os valores são criações humanas.

Enquanto que a volta de Nietzsche do rebanho autônomo aos novos filósofos está em perfeita concordância com a sua doutrina da vontade de poder, parece, contudo, que esta volta é irreconciliável com a doutrina do eterno retorno: como é que a demanda por algo absolutamente novo, essa desculpa intransigente para todo o passado, para que toda a 
"história" seja reconciliada com a afirmação ilimitada de tudo o que foi e é? No final do capítulo atual, Nietzsche dá uma sugestão sobre a conexão entre a demanda de filósofos totalmente novos e o eterno retorno; os filósofos do futuro, diz ele, devem suportar o peso da responsabilidade pelo futuro do homem. Ele originalmente publicou sua sugestão sobre o eterno retorno sob o título "Das grosste Schwergewicht" (O fardo mais pesado) (Gaia Ciência, aforismo 341).

Da recomendação dos novos filósofos, Nietzsche é naturalmente levado a julgar os filósofos contemporâneos, uma maioria, que não são filósofos em um sentido sério e apropriado, mas professores de filosofia, trabalhadores filosóficos ou, como eles vieram a chamarem-se após a morte de Nietzsche, homens que "fazem filosofia". Eles são no melhor dos casos, ou seja, apenas em casos raros, estudiosos ou cientistas, isto é, especialistas competentes e honestos que de direito devem ser subordinados à filosofia ou às servas da filosofia. O capítulo dedicado a este tipo de homem é intitulado “Wir Gelehrten” (Nós aprendemos); é o único do qual o título se utiliza a primeira pessoa do pronome pessoal: Nietzsche deseja enfatizar o fato de que, além de ser um precursor dos filósofos do futuro, ele pertence aos estudiosos e não, por exemplo, aos Poetas ou homines religiosi. A emancipação dos estudiosos ou cientistas da filosofia é de acordo com ele, apenas uma parte do movimento democrático, ou seja, da emancipação do baixo e de subordinação do alto. As coisas que observamos no século XX em relação às ciências do homem confirmam o diagnóstico de Nietzsche.

O caráter plebeu do erudito ou do cientista contemporâneo se deve ao fato de que ele não tem reverência por si mesmo e esta por sua vez se deve à sua falta de si, ao seu autoesquecimento, a consequência ou causa necessária de sua objetividade; por isso, ele não é mais "natureza" ou "natural”; ele só pode ser "genuíno" ou "autêntico". Originalmente, podese dizer, com algum exagero, o natural e o genuíno foram os mesmos (cf. Platão, Leis 642C 8d 1, 777 D 5-6; Rousseau, Do Contrato Social I. 9 extremidade e II 7, terceiro parágrafo). Nietzsche prepara decisivamente a substituição do natural pelo autêntico. Que ele faz isso e porque ele faz isso, talvez torne clara a seguinte consideração. Ele está preocupado mais imediatamente com os estudiosos e historiadores clássicos do que com os cientistas naturais (cf. aforismo 209). O estudo histórico chegou a estar mais perto da filosofia e, portanto, representa um perigo maior para ele do que a ciência natural. Este por sua vez foi uma consequência do que se pode chamar a historicização da filosofia, a alegada realização tornou 
verdadeira uma função do tempo (época histórica) ou fez toda filosofia pertencer a um tempo e lugar definido (país). A História toma o lugar da natureza, em consequência do fato que é o natural - e.g. os dons naturais que permitem que um homem para se tornar um filósofo não seja mais do que entendido como dado, mas como a aquisição de gerações anteriores (Aforismo 213; cf. Aurora, aforismo 540). O Historicismo é uma criança de tendência peculiarmente moderna para entender tudo em termos de sua gênese. Da sua produção humana: a natureza fornece apenas os materiais quase inúteis como em si-mesmos (Locke, Dois Tratados sobre o Governo II seção 43).

O filósofo, como diferenciado do estudioso ou do cientista, é o homem complementar a quem não só o homem, mas o resto da existência é justificada (ver aforismo 207); ele é o pico que não permite e ainda menos demanda para ser superada. Esta caracterização aplica-se, no entanto, estritamente falando apenas para os filósofos do futuro em comparação a homens da magnitude de Kant e Hegel que são apenas trabalhadores filosóficos, porque filósofos no sentido preciso criam valores. Nietzsche levanta a questão se existiram tais filósofos (aforismo 211). Ele parece responder afirmativamente a essa pergunta pelo que ele havia dito perto do início do sexto capítulo sobre Heráclito, Platão e Empédocles. Ou continua a ser verdade que devemos superar também os gregos (Gaia Ciência, aforismos 125, 340)? O filósofo como filósofo pertence ao futuro e estaria, portanto, a todo o momento em contradição com o seu Hoje; os filósofos sempre foram a má consciência de seu tempo. Eles pertenciam então aos seus tempos, na verdade, como pensou Hegel, sendo os filhos de seus tempos (Vorlesungen Über die Geschichte der Philosophie, Einleitung, ed. Hoffmeister, 149), mas por serem seus filhos adiantados (Schopenhauer como professor n. 3). Como pertencente ao seu tempo e ao seu lugar ou país, se apenas como seus filhos adultos, os precursores dos filósofos do futuro estão preocupados não apenas com a excelência do homem em geral, mas com a preservação da Europa que está ameaçado pela Rússia e que, portanto, deve se tornar uma Europa unida (aforismo 208): os filósofos do futuro devem se tornar governantes espirituais invisíveis de uma Europa unida sem se tornarem servos.

No sétimo capítulo, Nietzsche se volta para "nossas virtudes". No entanto, o "nós" cujas virtudes ele discute lá, não é o "nós estudiosos", mas "nós, europeus do tempo depois de amanhã, nós primogênitos do século XX" (Aforismo 214), "nós somos espíritos livres" (aforismo 227), ou seja, os precursores dos filósofos do futuro. A discussão das virtudes e dos vícios dos estudiosos deve ser complementada por uma discussão das virtudes e vícios dos 
espíritos livres. As virtudes dos espíritos livres foram discutidas no segundo capítulo, mas seus vícios inseparáveis de suas virtudes também devem ser descobertos. "Nossa" moral é caracterizada por uma ambiguidade fundamental; é inspirada pelo cristianismo e pelo anticristaníssimo. Pode-se dizer que "nossa" moralidade constitui um progresso além da moral das gerações precedentes, mas essa mudança não caminha para o orgulho; tal orgulho seria incompatível com "nosso" aumento da delicadeza em questões morais. Nietzsche está disposto a conceder que uma alta espiritualidade (Intelectualidade) é o produto final das qualidades morais, que é a síntese de todos os estados que se atribuem aos homens que são "apenas morais", que consiste na espiritualização da justiça e desse tipo de severidade que a conhece é comissionado para manter no mundo a ordem de classificação, mesmo entre as coisas e não apenas entre os homens. Sendo o homem complementar em quem o resto da existência é justificado (aforismo 207), em pé no topo da cimeira, e não sendo o topo, o filósofo tem uma responsabilidade cósmica. Mas "nossas virtudes" não são as virtudes do filósofo do futuro.

A concessão que Nietzsche faz aos homens que são "apenas moral", não o impede de tratar tanto dos ensinamentos morais reinantes (altruísmo, a identificação de bens com compaixão, utilitarismo), bem como de sua crítica aos moralistas como trivial, para não dizer com desprezo; a moralidade superior que flui, fez crítica ou tudo que é seu pressuposto não pertence a "nossas virtudes". As moralidades reinantes são inconscientes do caráter problemático da moralidade como busca, e isso se dá devido a sua consciência insuficiente da variedade de moralidades (cf. aforismo 186), a esses moralistas falta sentido histórico. O sentido histórico é a "nossa" virtude, mesmo "nossa grande virtude". É um fenômeno novo, não mais antigo do que o século XIX. É um fenômeno ambíguo. Sua raiz é a falta de autossuficiência da Europa plebeia, ou expressa a autocrítica da modernidade, sua ânsia por algo diferente, algo passado ou estrangeiro. Como uma consequência, "a medida é estranha para nós, estamos excitados pelo infinito e imensurável"; por isso estamos meio bárbaros. Parecia que este defeito, o lado reverso da nossa grande virtude, aponta para um modo de pensar e de viver que transcende o historicismo, para um pico mais alto do que todos os picos anteriores. A discussão sobre o sentido histórico (Aforismo 223-24) é cercada por uma discussão de compaixão (Aforismo 222 e 225): o sentido histórico medeia entre a moral plebeia que se orgulha de sua compaixão com aqueles que tem sido negligenciados por natureza (Aforismo 219) e tudo que é dobrado sobre a abolição de todo sofrimento e moralidade oposta que vai junto com a consciência das grandes coisas que você deve ao 
sofrimento (Aforismo 225). O próximo aforismo (226) é o único no capítulo com o título em itálico ("nós imoralistas"): nós imoralistas são "homens do dever"; "nosso" imoralismo é a nossa virtude. "Nossa virtude que nos resta" é a probidade, a probidade intelectual; ela é, pode-se dizer o lado positivo ou reverso de nosso imoralismo. Probidade inclui e completa "nossa grande virtude do sentido histórico", no entanto, a probidade é um fim ao invés de um começo; ela aponta para o passado ao invés do futuro; não é a virtude característica dos filósofos do futuro; isso deve ser apoiado, modificado, fortificado por "nossa mais delicada, mais disfarçada, a mais espiritual vontade de poder", que é direcionada para o futuro. Certamente a nossa probidade não deve ser permitida para se tornar o solo ou o objeto de nosso orgulho, por que isso nos levaria de volta ao moralismo (e ao teísmo).

Para uma melhor compreensão da "nossa virtude" é útil contrastá-lo com o mais poderoso antagonista, a moralidade pregada pelos utilitaristas ingleses que aceitam de fato o egoísmo como a base da moralidade, mas alega que o egoísmo justamente compreendido como à adoção do bem-estar geral. Que o utilitarismo é nojento, chato e ingênuo. Enquanto reconsidera o caráter fundamental do egoísmo, que não se percebe o fato de que o egoísmo é vontade de poder e inclui daí a crueldade que, como a crueldade direcionada a si mesmo, é efetiva na probidade intelectual, "a consciência intelectual".

Reconhecer a importância crucial da crueldade é indispensável se "o terrível texto básico homo natura", "esse eterno texto básico" é revisto, se o homem deve ser "retraduzido para a natureza". Essa retradução é completamente uma tarefa para o futuro: "nunca houve uma humanidade natural" (Vontade de Poder n. 120). O homem deve ser "feito natural" (vernatiirlicht) juntos "com a pura, e recentemente encontrada, natureza recém-redimida" (Gaia Ciência, aforismo 109). Pois o homem ainda não está fixado, ainda não é um animal estabelecido (aph. 62): homem torna-se natural adquirindo seu caráter final e fixo. Pela natureza de um ser em seu fim. Seu estado completo, seu pico (Aristóteles, Política 1252b 3234). "Eu também falo do 'retorno à natureza', embora não seja correto uma volta, mas uma subida à alta natureza, livre, até terrível e natural...." (Crepúsculo dos Ídolos, 'Escaramuças de um homem prematuro' n. 48). O homem atinge seu auge através e no filósofo do futuro como o homem verdadeiramente complementar em quem não só o homem, mas o resto da existência é justificado (aforismo 207). Ele é o primeiro homem que conscientemente cria valores com base na compreensão da vontade de poder como o fenômeno fundamental. Sua ação constitui a forma mais elevada da vontade mais espiritual de poder que é a forma mais 
elevada da vontade de poder. Com essa ação ele põe fim à regra do não-sentido e do acaso (aforismo 203). Como o ato da forma mais elevada da vontade do homem de impulsionar o Vernatürlichung (naturalização) do homem está ao mesmo tempo, no pico da antropomorfização do não-humano (ver Vontade de Poder n. 614), pois a maior vontade espiritual de poder consiste em prescrever à natureza, o que deveria ser (aforismo. 9). É assim que Nietzsche aboliu a diferença entre o mundo da aparência ou ficção (as interpretações) e o mundo verdadeiro (o texto) (Cf. Marx Nationalokonomie Und Philosophie, Die Frühschriften, ed. Landshut. pp. 235, 237, 273).

No entanto, é a história do homem até então, ou seja, o estado de não-sentido e do acaso, tudo o que é a condição necessária para o subjugo do não-sentido e do acaso. Em outros termos, o Vernatürlichung (naturalização) do homem que pressupõe e traz para a sua conclusão o todo do processo histórico - a conclusão que é de meios necessários, mas requer um novo ato criativo livre. Ainda assim, nessa história o caminho pode ser dito para ser integrado na natureza. Seja como for, não se pode dizer sim para os filósofos do futuro sem dizer sim ao passado. Ainda há uma grande diferença entre este e o ilimitado sim a tudo o que fez e é, ou seja, a afirmação do eterno retorno.

Em vez de explicar porque é necessário afirmar o eterno retorno, Nietzsche indica a maior conquista, como todas as altas realizações anteriores, é em última análise não o trabalho da razão, mas da natureza; em última análise todo pensamento depende de algo inabalável "profundo" sobre uma estupidez fundamental; a natureza do indivíduo, a natureza individual, não são perspectivas evidentes e universalmente válidas, parece que, é o fundamento de toda compreensão de valor ou conhecimento (Cf. aforismos 231; e 8). Há uma ordem de classificação das naturezas; na cúpula da hierarquia é o homem complementar. Sua supremacia é mostrada pelo fato de que ele resolve o mais alto, o mais difícil problema. Como já foi observada, para Nietzsche a natureza se tornou um problema e ainda assim ele não pode fazer nada sem a natureza. Podemos então dizer, se tornou um problema devido ao fato de que o homem está conquistando a natureza e não há limites atribuíveis a essa conquista. Como uma consequência, as pessoas passaram a pensar em abolir o sofrimento e a desigualdade. No entanto, o sofrimento e a desigualdade são os pré-requisitos da grandeza humana (Aforismo 239 e 257). Até agora o sofrimento e a desigualdade foram tomadas por concedido, como "dado", como impostas ao homem. Daí em diante, devem ser desejados. Por assim dizer, a regra horrível de não-sentido e do acaso, a natureza, o fato que quase todos os homens são 
fragmentos, coxos e acidentes horríveis, todo o presente e o passado é em si um fragmento, um enigma, um acidente horrível a menos que ele é seja desejado como uma ponte para o futuro (cf. Zaratustra, "da Redenção"). Ao pavimentar o caminho para o homem complementar, alguém deve ao mesmo tempo dizer ilimitado sim para os fragmentados e aleijados. A natureza, a eternidade da natureza, deve o seu ser a uma postulação, a um ato da vontade de poder por parte da natureza mais alta.

No final do sétimo capítulo, Nietzsche discute "a mulher e o homem" (ver aforismo 237). A transição aparentemente desajeitada para esse assunto - uma transição na qual ele questiona a verdade do que ele está prestes a dizer alegando que isso expressa apenas sua "profunda estupidez fundamental" - não é apenas uma lisonja, um gesto de cortesia aos amigos da emancipação da mulher. Isso indica que ele está prestes a continuar o tema da natureza, ou seja, a hierarquia natural, em plena consciência do problema da natureza.

Os filósofos do futuro podem pertencer a uma Europa unida, mas a Europa ainda é "Europe des nations et des patries" (Europa das nações e das pátrias). A Alemanha mais do que qualquer outra parte da Europa não-russa tem mais uma perspectiva de futuro do que, digamos, a França ou a Inglaterra (aforismos 240, 251, 255; cf. Heine ed. Elster IV 510). Pode-se achar que Nietzsche enfatiza em seu capítulo sobre povos e países mais os defeitos da Alemanha contemporânea do que as suas virtudes: não é tão difícil libertar o coração de uma pátria vitoriosa com um único golpe (p. 41). O alvo de sua crítica aqui não é a filosofia alemã, mas a música alemã, isto é, Richard Wagner. Mais precisamente, a nobreza europeia revela-se como o trabalho e a invenção da França, enquanto a comunidade europeia, o plebeísmo das ideias modernas, é o trabalho e a invenção da Inglaterra (aforismo 253).

Nietzsche prepara assim o último capítulo que ele intitulou "Was ist vornehm?” (O que é nobre?) "Vornehm" difere do "nobre" porque é inseparável da extração, origem, nascimento (Aurora, aforismo 199; Goethe Wilhelm Meister's Lehrjahre [Siimtliche Werke, Tempel-Klassiker, II 87-88] e Dichtung und Wahrheit, Vol. 2, ed. Cit. 44-45). Sendo o último capítulo de um prelúdio para uma filosofia do futuro, mostra a (uma) filosofia do futuro como refletida no meio da conduta, da vida; assim refletida a filosofia do futuro revela-se em si como a filosofia do futuro. As virtudes do filósofo do futuro diferem das virtudes platônicas: Nietzsche substitui a temperança e a justiça pela compaixão e a solidão (aforismo 284). Esta é uma ilustração entre muitos dos meios que ele significa ao caracterizar a natureza pelo seu 
"Vornehmheit" gentileza (aforismo 188). Die vornehme Natur ersetzt die göttliche Natur (A natureza nobre substitui a Natureza Divina $)^{9}$.

${ }^{9}$ Nota do tradutor: no texto original não foi disponibilizado a bibliografia. 